\title{
Uma Armadilha (para Lamartine): crítica à ontologia na literatura brasileira
}

Fecha de recepción: 7/7/2019. Fecha de aceptación: 31/7/2019.

\section{Resumo}

Este trabalho procura ensaiar uma crítica à ontologia fundamental na literatura brasileira através da abordagem do romance de Carlos Sussekind, Armadilha para Lamartine (1975) e apontando para outro romance do autor, Que pensam vocês que ele fez (1994), cujas publicações distanciam-se cerca de 20 anos no tempo. Tais romances, que podem ser entendidos como continuação descontínua um do outro, oferecem-se aqui como tempo, espaço e matéria para a crise e a crítica da metafísica da presença, da tradição representacional e da lógica da autenticidade, cujos conceitos perfazem as ardilosas construções ontológicas que foram cabais para os séculos XX e XXI.

Palavras-chave: Armadilha; Memória; Ontologia; Literatura brasileira.

A Trap (for Lamartine): Critique of Ontology from the Literature

\begin{abstract}
This work tries to rehearse a critique towards the fundamental ontology in Brazilian literature, focusing on the novel written by Carlos Sussekind, Trap for Lamartine (1975) and to point out at another novel by same author, What do you think he did (1994), whose publications distanced themselves about 20 years in time. These novels, which can be understood as discontinuous continuation of one another, are offered here as time, space and matter for the crisis and criticism of the metaphysics of presence, the representational tradition and the logic of
\end{abstract}


authenticity, whose concepts make up the ontological cunning constructions, which were absolute for the twentieth and twenty-first centuries.

Keywords: Trap; Memory; Ontology; Brazilian literature.

\section{A.}

O enredo emaranhado de linguagem oferecido à dissolução da identidade e do sujeitona época na qual eles se encontram como a um todo atados sob o jugo do que se conhece por presença a si mesma de si mesmo e suas derivações por vezes as mais encantadoras, imbrica-se, na construção em si desconstrução de Armadilha para Lamartine tal como um olhar a uma tela que passa - invasiva mirada ou morada, invasiva escuta imbricada ao punho, sangue e letra do outro empunhada ao outro, outramente letra que ser. Evasiva também. Memória do quê. Labirinto. Por vir nem sempre para ser. Mas parecer. Ou mentir. Obliquamente sentir. Linguagem d'uma voz narrativa entretecida. Não exatamente racionada, repartida. Dobrada talvez compartida. Diluída. Ou subtraída. Publicada em 1975, como sabemos, a plenos pulmões a operação condor, a Armadilha incrusta-se à crítica ao estado das coisas muitas vezes tal qual se apresenta hoje, "a exceção é a regra”. Assim, atualidades, autoridades, alteridades aparentes. E a Armadilha opera isso sub-repticiamente. Um pouco por meio da duplicidade constitutiva de um logro. Tornando-se multiplicidade. Uma assinatura dúbia, Carlos \& Carlos Sussekind. Inventada, incorporada. Espanto. Confundida a obra desdobra. Fora da autenticidade. Garantias quaisquer tampouco. Em 1975 já não fora um livro desapercebidamente publicado. Eventualmente tratado por "memorialista", passado por, talvez, recebido como -já não deixava evidenciar de imediato que rompia interrompia de veras o funcionamento do aparelhamento oligárquico de linguagem da sociedade burguesa tardo-capital, policial e gerencial, e o funcionamento das amarras todas, das simplificações narrativas mais adjacentes aos esquadrinhamentos de gênero os mais diversos, raça, cidadãos incluídos adequados à manutenção da ordem social, assim à comunicação com o todo no todo que seja,que seja adequado.Falso adequado. Por isso passou.- Poderíamos pensar, então, que fora este o seu mais próprio "teste de realidade". Ironicamente trata-se de uma Armadilha.A textura de uma teia, ausente a aranha. Essa textura emaranhada junto aos vincos do tempo, não obstante. Fende. Escande.Não o tempo narrado estritamente, mas o próprio, no qual o funcionamento geral e o anestesiamento da consciência desse funcionamento e por assim a debilidade social,corroem-se, corrompidos ali por uma "telepática" escritura feita, torneada, tornada ante - finalmente brincadeira. Avante também. Equívoca, por suposto. Suporta em muitos momentos uma ficção não apenas sob a "ausência" do narrador, por assim dizer enquanto sujeito ausente na sociedade da ausência regente, uma ausência plena, ou só pluma, uma pena?, - mas também, principalmente, suporta um labirinto: muros aparentes emface de um texto sem pai, o abismo da Armadilha, o chão em si da ausência. Própria? Paradoxalmente, sua textura imprópria, torna-se, por assim dizer, o limiar do controle um tanto fora do controle da presença. - E 
foi nesse buraco que, devo dizer, me meti, sem encontrar o que seja. E, depois de certo ponto, pensei, haveria retorno? Talvez,- apesar do empenho de uma textura esburacada.

\section{B.}

Recordo as palavras de Jacques Derrida, em Timpanizar - a filosofia: "O que então se trama aqui não faz o jogo de um encadeamento. Mais do que isso. Ele joga o encadeamento. Não esquecer que tramar (trameare), é antes de mais furar, atravessar, trabalhar de um lado e de outro da cadeia." (1991 [1972]: 18). Ora, o que a Armadilha configura materialmente e inclusive "sem imagens"e por isso ao mesmo tempo desfigura em sua arquitextura labiríntica, vale dizer, timpânica arquimembrana que é papel, tramado, todo espicaçado, martelado, parece transparece passar adstrito à decomposição de um sentir próprio impróprio, a decomposição de uma ausência. A desloucura da razão de uma loucura. A desmemória das memórias do diário. Espécie de crise da presença. A Armadilha não atém seus desígnios, por vezes os mais escusos, à capacidade recorrente e "infinita" de um eu que o seja narrador ou diarista de lograr dizer o "seu" outro junto àcópia microcósmica do todo e os ecos do ser.Ironicamente, desequilibra, antes, o logro próprio do que éo "seu", o ser no limite das tentativas e das tratativas para dizer o outro. Reconhecê-lo, talvez reapropriá-lo. Retorná-lo ao domínio do que é, presente do indicativo no estado das coisas. Ao que sempre é porque é, a-pesar o autor, existência segura de um entendimento refletido espelhando idealmente interior e exterior.Por isso também não se entrega meramente ao crítico que o valha. Arma a Armadilha um abismo para -. Aparência limítrofe doeu.Doeu o outro. Impressão ali que não exatamente se deixa imprimir. Quase uma pegada na areia ou na lama, depois que vem a chuva. Apresença do que já não está, o que já não é. Arma-se. Isso nem sempre se deixa ver. Deixando-se vir a não ser. Assim,talvez,torna-se essaArmadilha dispositivo de passagem contra as artimanhas e os ardis do logos hegemônico em operação constante na civilização ocidental, esclarecida ou vulgar, por assim dizer -arma, arco e flecha contra o logos que logra de fato amortecer ou equilibrar as pressões, expressões ou impressões, enfim, dissonâncias das mais variadas percussões chocantes e heterogêneas. Corpo, forma matéria, diferença, emboscada de certo, manobra textual inapropriável no mais, inconcebível como "sua”. Soa, contudo. Sonha. Talvez filosofa, mas com o martelo. Vertigem labiríntica, perturbação. Labirinto, tímpano, martelo etc. "Ouvir com os olhos", Nietzsche. Intestino. - "Trata-se infatigavelmente do ouvido", Derrida. Então, algo aqui se permite martelar como crítica ao proprius acontecimento entregue originalmente à fala pertencente, ou ao seu ideal, aos seus ecos ou fantoches. Crítica à presentificação evidente de um desejo assimilado que seja, isso e aquilo e outro tomados por acontecentes assim desde sempre e somente para locupletar que me escuta ao ser sem resto perfazendo-se o próprio do que é ser entregue à luz e ao serviço do pensamento, da idéia ou do mestre, da identidade e do imperar arrazoado de uma essência existência aí afim à exequibilidade total e à comensurabilidade eà realizabilidade 
da linguagem usada deveras não-usada hoje. 0 jargão da autenticidade. $\mathrm{O}$ funcionamento de uma ordem. Inomináveis sacrifícios. As operações de fundamentação "religiosa", sacra, separada, alienada de um uso de fato fazem escola. São jurídicas. Médicas. Governamentais. “Práticas” orientadas à conservação do sistema social vigente. $O$ sagrado na era do utilitarismo total. A autoconservação. Não são desconhecidas as forças, as pujanças das máquinas administrativas, linguísticas ou neurofilosóficas as quais podem meramente "refletir sem horror" a sua participação no "cortejo triunfal". Hoje. Destinadas ao que são. Sanidades do são. A perpetuar as vozes, a perpassar os ecos de todos os que antes já foram existência, atravessados pelo ser. A sobrepujar até aqui outrem também. - Mas quem escuta os "ecos das vozes que emudeceram"? Tudo se presta com o jargão a perpetrar. Aceitar o todo sem revoltas. Herança aos “ouvidos dóceis",os ecos do ser. Aristocracia inata no íntimo. Céu, mar, oceano, sentimento, horizonte, tudo a ser conquistado. Impressão de tranquilidade. Certeza de algo. Existo. - Tu, existes? Não importa em qual tubo de ensaio. 0 amparo resguardar-se-ia sob o signo da autenticidade. Formando entes adaptados à inadaptabilidade total, à docilização prática, com escrutínio. Sendo, pois, linguagem, a diferença exangue. Aqui, contudo, ante a presente ausente Armadilha recua a linguagem do ser, o esquema metafísico da escutado ser deixa cair a sua máscara. Ou uma máscara que já não seja.Aqui não, eco vitorioso do ser fatídico!Então cai uma máscara, o solo se abre, vulcanizam-se toneladas de sangue, gente e lama, mas essa imagem não precisa "aparecer" na Armadilha.

\section{C.}

A crítica às tratativas para o controle do infinito em instância do ser, do sendo propriamente assegurado e mais íntimo, talvez seja mais facilmente perceptível, na Armadilha, se apontarmos, desenho, arco e flecha, tal como a criação do personagem-narrador, atacarmos alguns dos fundamentos racionais da tradição narrativa, os quais se encontram em apuros nesse romance, ruinando. Sergio Barcellos, em sua dissertação sobre o tema, sugere que a "investigação subliminar da linguagem", tal como se deixa transparecer na Armadilha, colocaria em crise "a hegemonia da causalidade e a expectativa de univocidade da voz narrativa" assim como acontece em Mulholland Drive, de David Lynch, ele argumenta (Barcellos, 2004: 13). As dimensões da construção desconstrução do romance Armadilha tangenciam-se obliquamente e adstringem-se fantasticamente ao espaço-tempo que se abre às folhas, papéis, capas, ficha editorial e orelhas que dispõem a respeito de um objeto ainda não. Muitos quadros. Telas. Buracos. Significa que esta Armadilha não reserva espaço para a narração senão por completo, como sabemos, todo espicaçado. Ruinando hegemonia, causalidade, univocidade. Não se deixa capturar fora por invariantes. Ocupa esta ficção apenas todo o ar rarefeito do espaço que necessita para si. O tempo. Capa a capa. Ficha, autor, autores. É evidente que a assinatura Carlos \& Carlos Sussekind provoca imediatamente ranhuras imagéticas na expectativa de unicidade da voz, soerguida que está normalmente por autorreferentes racionalidades há 
muito hegemônicas na administração da vida em sociedade e cujas consequências todas literalmente possíveis se podem dispor de forma lógica e causal, para a determinação absoluta do que é e do que não é. Ali, porém, encontra-se em apuros, no tempo, a unicidade, desde o momento da assinatura, na Armadilha. Intestino selvagem da voz. Embrulhando o presente ausente. Ruminada escuta que não advém do ainda-não-ser e nem se presentifica indicativo originária ao que só depois outrem. A dupla assinatura fantasmática dispara um feixe, pois. São flechas. A multiplicidade, só aparentemente arregimentada em ser no curso de sentido único das sociedades ocidentais, abre a caixa da potência da sua fragmentariedade. 0 "eu pó e cinzas", conforme já escrevera Franz Rosenzweig. - Curiosamente, pergunto, poderemos tratar esse Doppelgänger de fato como o "autor"? Nada abstrato. Faz desfaz a figura. Sempre novamente. Pai, dançando, pedaçando pensamentos. Filho. Feito brincadeira. Dispositivo. Intrinca a lógica do controle objetivo. E a primeira página da Armadilha instaura um romance sem centro. A primeira frase desde já. Um enigma, de certo, primeiro a respeito do narrador, que perde ou entrega o controle da sua evidência: Dr. Espártaco M. possui um diário. Lamartine é filho de Espártaco e esteve num hospital psiquiátrico. 0 diário é recortado apenas para adstringir-se ao período que teria o condão de comportar os momentos precedentes à crise de Lamartine até ser internado, comportando também assim a vivência da sua família no período do internamento. "Sob o título geral de Armadilha para Lamartine acham-se reunidas": partes do Diário de Espártaco (de 1954-55) e duas Mensagens de Lamartine escritas no sanatório. Essa é a sua primeira face. Para Fabio Bortolazzo Pinto, que escreveu uma dissertação sobre o tema, a "impressão de ausência de narrador se dá justamente pelo fato de que, tanto o diário do pai quanto o relato do filho no sanatório são apresentados como documentos colocados lado a lado" (Pinto, 2005: 5). Para Markus Lasch chama-se isso "metaficção", essa textura desdobraria,porém, uma tendência à unidade, porque "o livro aberto e ao mesmo tempo fechado que se converterá na armadilha para o filho é também ele que constituirá a sua salvação. [...] Ao instituir-se nela ou por ela [i. e., na ou pela literatura], o eu sempre e necessariamente se institui como outro" (Lasch, 2009: 246). Logro desvio para ser, aparentemente a instituir, antes substituir. Poder. Ora, a Armadilha que se achou a si mesma reunida a ponta ou espectra, antes, incerta,incômoda multiplicidade de sentidos, a respeito dos quais apenas se torna possível num átimo vislumbrar a distância até a qual se pode perder um plano de fundo até se tornar insuportável uma ausência, e sem que se possa lograr exigir um sujeito de pensamento a pensá-lo, determiná-lo, esquadrinhá-lo,ante a uma trágica agora cômica ciranda sem chão. Agora. Junto à desagregação do sujeito, unicidade, causalidade, fórmula, instrumentalidade, sanidade, etc., prostram-se, outrossim. Aqui, na antessala ainda, o fato de "acharem-se reunidos" tais materiais, leva a virarem-se, desvirarem, desviarem talvez antecipadamente as corolas desta ficção para a escusa ou escura problematização da experiência danificada em toda a ordem da sua enunciação. É uma burla a Armadilha. Essa que se monta, anunciando textos escritos por pessoas diferentes, pai e filho, este se fazendo passar por outro, inclusive, além. Outros. Não é ser. Não é são. Algo como ludibriar, libidinar. Carrega por onde passa esta Armadilha o ar escasseado da vida 
"priápica”. ' Cômica. Então, a forma lógico-positivista de elencar coisas está ali realmente para clarear essa primeira página, depois trair a si mesma nas páginas seguintes, umas após as outras, e sempre de novo. Trair o eu que fosse outro. Como numa brincadeira. A Armadilha instaura um equívoco, pois. Mensagens. Diários.Memórias. Faz-se passar. Ficcionar. - Haverá, contudo, com olhos, ouvidos e martelos, um sujeito abstrusoa manobrar passagem alguma em bastidores totalmente obscuros, crendo-se a si mesmo inventor da Armadilha, o criador?

D.

Ora, é relevante notarmos que o desconcertante jogo de espelhos quebrados e de desaparecimentos e de supressões e confusões de imagens e vozes narrativas parecem entretecidos buracos de incerto a "falsificar a idéia de um colapso total" por toda esta Armadilha.Qual colapso!O colapso "da hipertrofia da atividade racional" do eu em contato com a "ex-centricidade" (Pellegrino, 1991 [1976]: 280). Lamartine aponta e a Armadilha apronta-se para isso. A crítica da natureza da presença nos diários do pai. É cinza. O colapso sempre já acontecido enquanto Espártaco escrevia suas palavras, cabalmente cingido estava junto ao manejamento biopolítico e ao funcionamento do Estado. A pintura de um pai. Feitura. Escorrendo girassóis.Que fossem capazes de escorrer, escoar borrando a idéia de representação do sujeito, de si mesmo ou enquanto objeto. Escorrer a idéia que a si mesma acreditou-se e um dia tornou-se capaz de substitui-los ou possui-los todos, filosófica e juridicamente, numa identidade determinada de eu, não-eu ou mesmo de classe, numa passagem crítica do eu ao nós em crise social e corpo dócil, entregue às diversas determinações correntes à produção do gênero literário no seio da qual emerge esta Armadilha.Emerge a falsificar um colapso para a escritura em si de uma vida vivida não mais vivida, às margens da qual se desagrega a idéia mesma de identificação e de substituição e organização e as sóbrias roupagenspara a descrição e os registroslúcidos e os controles dos acontecimentos de fato apropriantespor um falso aí eu penso. Tal inautêntico colapso se alimentada própria crise que instauraum corpo de linguagem e a si mesmo parece devorar-seem abismo, junto aos melindres e aos meandros de uma escritura não meramente reconduzível ao aí de uma síntese social, em sua disseminada e dispersafragmentação jamais assente em solo seguro,deixandocompor-se assim um "espaço multidimensional" de artifícios, no qual as personagens se encontram em "constante canibalização e autofagia” (Barcellos, 2004: 52).Literofagia.Imagofagia. Duas personagens, carácteres "ao mesmo tempo distintos e idênticos - a cabeça e o rabo da mesma serpente, em um processo de autodevoração constitutiva” (Barcellos, 2004: 78). A Armadilha insinua um colapso talnas relações com a escrituraque a sua composição tornada decomposição doravante não poderia ser reconfortada

1 De Priapismo: ereção involuntária e dolorosa do pênis, sintomática de diversas doenças. Excitação sexual exagerada. Disso padeceram Espártaco e Lamartine, nesta Armadilha para Lamartine. 
para dentro das margens e dos esquadros e ninhos conceituais que externa e objetivamente contribuem para a direção anônima e cínica de uma sociedade de fato regida pela abstração das suas relações o mais das vezes naturalizadas. Em cacos, em grãos, as capacidades lógicas de transformar tudo imediatamente em esquema comunicável e de reconstruir retrospectiva e compreensivelmente as molduras sociais capazes de suportar um vazio que avança sobre um corpo de linguagem não logram mais devolver à classe ou ao sujeito que seja não-eu de fato o governo de um sentido. Nesse sentido, pois, se a Armadilha apresenta uma espécie de "denúncia da fragilidade de uma estrutura política, econômica e social prestes a convulsionar-se", conforme escreveu Bortolazzo Pinto (2004: 119), devo ressaltar que essa denúncia não necessariamente pode ou deve conduzir-se ou conduzir-nos para fora da ficção, ou melhor, para a aplicabilidade técnica utilitária (do chorume) dela, mas, antes, uma tal convulsão ou colapso deve levar, fazer passar ou transitar para o abismo nela, na ficção.O ardente acinzentamento da noção de sujeito e da função de narrador nesta Armadilha produz-se então por meio do jogo único com a aparência de sinceridade e de sanidade do texto exposto, já que obviamente não existe a menor garantia quanto ao retorno destes ao conforto apaziguado de um estado de fato, tampouco a uma estante social ou mesmo a uma biblioteca estanque, seja pública ou privada, que pudesse lograr suspender ou anestesiar a crise que a sua desagregação provoca nas expectativas sociais que podem sempre reapresentarem-se com os seus baluartes e bandeiras de significação dada. Aberto o diário, exsurgem os monstros. - Do sono da razão? O sono da loucura?

\section{E.}

Para Luiz Costa Lima trataria a Armadilha de um "acesso oferecido a uma classe social". Motivo pelo qual também podemos entender que o movimento para a sua compreensão, a saber, o momento desfecho da constrição do ambíguo e enigmático, ali armado fragilmente, estaria ele mesmo às voltas com o vazio. No plural: "o entendimento destes vazios será importante para a compreensão dos dilemas sociais de uma época de nossa história” (Costa Lima, 1981 [1979]: 128 e 129).Cinza - ou seja, para esquivar-se a alienação ahistórica, a compreensão servirá para a reconvocação de uma voz de conhecimento que enquanto sujeito esteja sujeita ao sistema de coordenadas rígidas, as quais de direito a Armadilha tematizaria e refletiria.Ora, talvez porque a montagem desmontagem da aparência de um estado de coisas nesta Armadilha imiscua-se ao mortificado e seja levada a traição ao comunicado, rebelando-se inventiva criação poética contra a identidade e as suas determinações sociais mais evidentes, seja ainda outro motivo para que se postule uma teoria que o valha a correspondência entre o que aparentemente "vive" ou "fala" na Armadilha e uma sua essência social que a animaria e resguardaria por fim. Isso fomenta uma política régia na literatura, tal qual se pode ver "na prática”, por assim dizer, uma estratégia esteticizada e a si mesma subjugada às mais realistas corporações sem corpos, sociais,togadas, engravatadas ou 
de jalecos, tornando-se a si irreflexão como presa a uma confirmação resignada, no mais consoladora, acolhida num clima existencial.Senão vejamos, palavras de Costa Lima:

\begin{abstract}
A exploração memorialista, recorrendo à figura de um eu conjunturalmente convertido em um outro, em uma alteridade estranha, termina por se transformar numa indagação antropologicamente destacada da classe produtora e receptora de romances, no Brasil. As tensões internas a esta classe não haviam sido suficientes para romper a divisão interna de Espártaco; os tranquilizantes ainda o acomodam. Tampouco a crise de afirmação de Lamartine; o sanatório ainda consegue 'curá-lo'. (Costa Lima, 1981 [1979]: 135.)
\end{abstract}

Uma abordagem hoje aquém da necessidade não ontológica da coisa que o valha. Seria a Armadilha misto de memorialismo antropológico que sobreviveria ao seu ponto crítico. Nela, as tensões internas de uma classe não seriam ainda suficientes para. São as tensões externas à ficção, então, que não seriam suficientes para um rompimento final na ficção, indicando que o significado de rompimento depende da estrutura social. No caso de não ser tal rompimento o desígnio mesmo de um pensamento preso ao todo do estado das coisas, por exemplo, nesse caso, a narrativa teria a chance de perder-se outra vez no abismo, no qual foi quase capturada. Entendo a citação acima, então, como um fecho externo de poder frente ao perigo de fato da dissolução, da qual o pensamento procura se resguardar. Mesmo que subsidiada pela compreensão de acordo com a qual a Armadilha aponta para o tempo, vale dizer, para além de si mesma, por tornar-se "variante" ao fechamento memorialista, contudo, vê-se esta perspectiva obliterada pela vontade e pela capacidade de aplicabilidade técnica de uma visão realista fantástica no mais alto grau de conhecimento. Uma visão que se entrega ao jugo do sendo existência aí em forma, informa, portanto, o ser, performa-o destinado a - e assim entrega ao todo a vida mesma por fim.Aí lógica. Cura a idéia dá. Conseguir perpassa. “A rigor, onde haverá lógica na vida?", já teria se perguntado Espártaco na Armadilha. Tornando a existência autoproclamada o critério do pensamento, o pensamento pode encontrar sempre a sua imagem na realidade racionalizada. Pode performatizar o próprio aprisionamento da consciência, nas mais regulares, racionais e justificáveis ações. Recepcioná-lo. Talvez junto à fatalidade do encantamento e o exercício de um poder. Costa Lima argumenta que a Armadilha tornou-se uma variante memorialista, porque em seus trilhos correu a voz ou a língua miscigenada ao outro que seja ou que fosse, a ter sido, antropológica corrente. Com as amarras até, rompeu a Armadilha. Romp-eu. De constituição ela mesma rompida adviria como um protótipo da consciência de uma "classe social", porém. Aí adstrita, e não a si mesma. De fato, a análise de Costa Lima é um fecho porque tampa buraco. Ter sido tomada ou transformada a Armadilha ou ter transformado a si mesma numa indagação significaria ali indagar uma "classe", e isso é entendido, no limite, em sentido organizacional, a saber, lógico em relação ao controle do microtodo social retratado, tal como a classe mesma ali deveria ser-estar, se fazer passar, no fluxo da mania de presença do logos hegemônico, de certo acalmando a inquietude intelectual de uma administração integral, ela mesma insustentável. Ora, entendida assim, a Armadilha poderia ou deveria figurar, paradoxalmente, no próprio quadro descrito pelo 
sujeito do conhecimento e não o contrário, o sujeito desaparecer ou esvair-se as suas forças ante a Armadilha. Uma tal administração vital da ficção,obviamente,já não pode mais restringir a evidencia dos seus efeitos àquilo que concerne objetiva ou estritamente à "teoria”, o que quer que isso possa hoje significar. Diante dessa Armadilha dificilmente se escapa por meio da estética da recepção ou de uma estrutura outra qualquer que o valha, corretamente determinadas para um objeto " $x$ " do conhecimento feito para entrar e não mais sair do laboratório, preso ao ideal de eu, de língua ou ao sujeito histórico no mais.- Adstrito à Armadilha,apenas o pavor do fragmentário transita por meio das mais obsessivas elucubrações e construções de sentido entregue sa força à "racionalidade" social. Arma a Armadilha um ataque desde dentro contra os limites impostos de fora pela sociedade, ou pela sua "visão". Com flechas. Um índio de uma única pena. Dispara. Apontadas desde a ficção para a ficção em abismo, decaindo assim o cenário de uma vida administrada, usurpada. Cenário no qual a consciência se tornou definitivamente reificada. Maltratada. Enquanto idéia ou enquanto tal. Choque. Memória. Provoca um próprio estado de exceção. Corpos e corpos de linguagens despedaçados, fendendo a dimensão hegemônica da compreensão em escala industrial, vertida em desespero. Um monumento admiravelmente em ruínas.

\section{F.}

As relações entre controle social e sem fundo do poço do poço do poço da imaginação poética pode ser lida também, talvez com mais evidência, se pudermos avistar o deslocamento de alguns espectros não personagens nesta ficção, que ali, contudo, transparecem, deixando um rastro anônimo, sem exigir diretamente uma comunicação. Considero importante, principalmente, lembrar van Gogh, cujas obras Lamartine adorava e algumas possuía cópias, assim como adorava e lia muito Nietzsche, dentre outros. Cristo também. Ingmar Bergman. 0 estopim da crise que assaltara Lamartine teria sido o filme Noites de circo, de Bergman, que, como sabemos, o próprio realizador afirmou: "teve como ponto de partida um sonho" (Bergman, 1996: 184). Também Spinoza, uma máquina - mas depois, só depois em $O$ que pensam vocês que ele fez. Ainda todas as referências de Espártaco. Bom, diversos são esses espectros que transitam não como personagens pela Armadilha. São realizadores, dramaturgos, escritores, pintores que decompõem um dia a dia familiar, cruzam-se olhos ou dão-se as mãos no ambiente aparentemente apaziguado de uma família burguesa: um dos quadros de van Gogh que tinha Lamartine haveria de ficar representando-o, pendurado na parede, após a sua saída da casa paterna. No curso desse abismo de linguagem que se dá a ver nesta Armadilha, Lamartine, Espártaco e os seus constantemente dirigiam-se ao cinema. E de certa forma isso conduz o sensível ali para incerta espessura de sombra e caracteres projetada à frente ou atrás por meio de um vazio constitutivo aos âmbitos da presença nesta ficção, escandalosamente inseparável da vida. Espectros, de certo, também são os próprios nomes Lamartine e Espártaco, que provocam cinza a escatológica inquietude de conotações não evidentes. Já bem 
notou Costa Lima que não devemos aceitar para esta Armadilha determinados esquemas duais, de acordo com os quais apareceriam como meramente opostos o lirismo angustiado e incompreendido de um filho e a seriedade protocolar e o racionalismo patriarca do pai. Mesmo os muros do sanatório não poderiam indicar então uma separação decisiva entre loucura e razão, dentro e fora, talvez, eu e outro, ser e não ser. "Esta suposta separação não passa de uma armadilha. Por baixo dos muros existe uma rede subterrânea a comunicar os espaços, convertendo-os em seguimentos do mesmo horizonte" (Costa Lima, 1981 [1979]: 130). Ainda segundo Costa Lima, "o choque entre a perspectiva dos 'sãos' e a dos loucos acerca da instituição hospitalar resulta de que os primeiros a entendem ao pé da letra, ao passo que os segundos são obrigados a descobrir a força da metáfora", e por esse motivo se tornaria, nesta ficção, "o mundo reservado aos sãos uma armadilha das palavras: são é apenas o falso plural do é burguês” (1981 [1979]: 129).- Há uma carta de Lamartine sobre o horizonte "arquivada" por Espártaco que talvez relacione-se com isso. Lamartine teria escrito cartas e bilhetes que seriam algumas vezes arquivados no Diário do Espártaco, talvez como meio de provar algo, caso o futuro o exigisse, quem sabe. Para Hélio Pellegrino, no que concerne à narrativa que provém mais “seguramente"de dentro do sanatório, a saber, as duas mensagens escritas por Lamartine fazendo-se passar por Ricardinho, e que posteriormente teriam sido também “arquivadas" por Espártaco, tal narrativa, pois, "corresponderia ao nervo secreto, inconsciente e informulado do Diário" (Pellegrino, 1991 [1976]: 280). Há uma passagem aqui também. O que não significa nem mostra uma correspondência direta, mas antes de forma a idéia de uma tal correspondência, a qual se perde em nebulosas relações.Talvez o mais sintomático e labiríntico bilhete desta Armadilha tenha sido aquele por meio do qual Lamartine pediu ao Espártaco -quem vinha sendo pressionado pela esposa a largar de mão o Diário -que não o fizesse, que continuasse de fato a escrevê-lo. Assim, parece, a Armadilha excede a textura das palavras que recolhe para expor-se a uma abertura do espaço no tempo de uma intimidade vazia cheia de algo, mas pública, cujas entranhas, às vezes expelidas outras eletrochocadas, inconvenientemente confundem-se com a ambivalência das sombras que por ventura podem tocar os corpos de linguagem que penumbram eles mesmos e comungam dessa sombra. A Armadilha parece deixar transparecer em trama o que talvez não seja trauma, mas que tampouco pode subsistir, fragilmente, senão a exceder a exceção: frente a qualquer atenuação ou amansamento da linguagem corrente, ela usurpa a aparência da matéria convencional do Diário de Espártaco que visava certa obliteração: a "ocultação da 'outra cena', do lugar ex-cêntrico em relação às posições, às posturas e imposturas conscientes do ego" (Pellegrino, 1991 [1976]: 280). A Armadilha não revela o que estaria oculto. Deixa transparecer apenas uma fissura das trevas para dentro da qual se expandem não apenas os momentos de invisibilidade junto à crise e à mania de visão recorrente nas sociedades tardo-capitais, mas, sobretudo, os momentos impalpáveis ainda que sensíveis do amor indeterminado às sombras, junto às pregas de uma inquietude infinitamente aberta, exposta, num qualquer movimento de vai e vem arquitextualmente recomeçado. Fora da lógica binária para o tratamento da realidade pensada tradicionalmente desde as artimanhas de um esquema ou... ou de pensamento, arma esta Armadilha as coincidentia oppositorum que,como 
faces não figuradas da linguagem de sua multiplicidade constitutiva, alcançam no mais das vezes por via transversa e subliminar o constrangimento próprio dos raciocínios os quais gostariam de reger o tumultuoso torvelinho das relações entre conhecimento, ciência e poder. Frente a uma tal lógica,a conjunção por assim dizer e...e nesta Armadilha não é senão também forma à disjunção.

\section{G.}

O Diário da Varandola, telepaticamente lido por Lamartine para seus consortes no sanatório, durante os dois meses em que lá esteve, estaria sendo escrito por Espártaco em seu gabinete, a saber, o espaço da varanda do apartamento familiar, o qual ocupava, e que depois, inclusive, pudera Lamartine ocupar, só depois. Por isso chama-se Diário da Varandola-Gabinete esta fração de tempo e espaço que toma a maior parte da Armadilha. Parece relevante assinalar que o trabalho misterioso da memória nessa Armadilha lembra uma imagem dialética que Walter Benjamin apontou em Infância berlinense, as Loggien, a saber, as varandas dos prédios da zona ocidental de Berlim, as quais voltavam-se para o pátio comum dessas habitações e nas quais muitas vezes estendiam-se e batiam-se os tapetes das famílias que ali residiam: "era uma abertura no empedrado", ele escreveu, onde se formavam os seus sonhos: "a manhã, quando eu a encontrava na nossa varanda, parecia ser manhã há mais tempo, [...] eu nunca conseguia esperar por ela, era sempre ela a esperar por mim. Estava sempre já lá, como que fora de moda, quando eu finalmente dava por ela”, acrescenta Benjamin (2004 [1932]: 74). Ora, tal manhã varanda arquitextual transparece o que está por vir como se já passado fosse e em seu seio dificilmente se permite ao que transita, firmar ou afirmar a si mesmo alguma coisa ao seu lado: abre de forma plástica a perspectiva de um espaço em si aparentemente fechado. De acordo com Benjamin, a criança que um dia se aninhou aí, na varanda, "instala-se como num mausoléu que há muito lhe estava destinado" (Benjamin, 2004 [1932]: 76).Talvez vejamos, nesse âmbito, um espectro desta Armadilha, em cadeira de ferro ou de madeira sentado, à tardinha, reunido com os outros ou com os seus, num circulo de leitura. E, assim,a "capacidade de interpolar infinitamente aquilo que já foi", desperta, pois, a cada dia para o encontro com o novo dia da criação, deixando transparecer justamente o que se insinua cair no seio vazio cheio de algo das criações de papel, tais como se armam na presente ausente Armadilha. E para além dela, como em outras varandas. Pois, as relações para a tessitura e o apagamento de uma autoria que seja e a emergência criativa de uma experiência pedra, papel, tesoura de memória tornaram-se ainda mais ambivalentes e multidimensionais em sua profusão crítica espectral e em sua abertura ao passado após a publicação (cerca de vinte anos depois da Armadilha) do romance Que pensam vocês que ele fez, em 1994, dessa vez assinado apenas por Carlos Sussekind. Novamente as personagens principais e a temática dispersam-se em seu falso fundo capa a capa: Espártaco, Lamartine, diários, memórias. Mas, brincadeiras sobre tudo. Invenções. São montadas de forma a duvidar a respeito do que veio a ser narrado antes ou depois. Confundem-se os tempos. Assim, Que pensam vocês afetou 
obliquamente a Armadilha, de certo tornando-se outra armadilha, vindo a não ser, montada e caída já frente ao abismo de ser. Porque esta outra ficção alocando-se criticamente dentro da anterior ou a anterior dentro desta, traz consigo para mais fundo no abismo uma equivocidade tamanha que se torna capaz de ruinar a aparência de tudo o que poderia acreditar circunscrever-se à imaginação segura da Armadilha. Trata-se do futuro que foi - ou não foi?

\section{H.}

O Diário do Futuro, em $O$ que pensam vocês que ele fez,era escrito concomitantemente aos Diários "regulares" por Espártaco. Fantasiava a sua família cerca de vinte anos à frente. Aí, os "índices de desintegração da personalidade" atingem um ponto de não retorno no abismo no qual literalmente não se encontra o que seja e no qual o rompimento nevrálgico de uma textura de linguagem que se cria digna a respeito do que é torna-se, pois, a sua própria ruína. Resumidamente falando: a dimensão temporal da escritura se volta contra ela. Os diários do futuro teriam sido escritos nos anos 1930 até 47, ano em que Espártaco sairia de casa, rompendo com a família, por motivos que não vêm de fato à tona nessas arquitexturas. 0 tempo narrativo de preparação por Lamartine da segunda armadilha que veio a ser o romance Que pensam vocês remonta a 1972, vislumbrando o passado, os Diários do pai perdido. A Armadilha propriamente intitulada, portanto, cujo tempo de narração remonta a 1954-55passa e torna-se espectro dela mesma, já que a leitura abismal dessa desconstrução indica a impossibilidade de Espártaco ter de fato escrito o Diário, que havia se tornado o espaço de um terreno tempo sem chão no qual Lamartine flutuou e ofereceu telepaticamente à sanidade social quando sequestrado estava pelo aparato repressivo autoritário privado-estatal de controle e docilização da vida. Incrivelmente a Armadilha vê-se capturada por outra armadilha, a linguagem pela linguagem, pela textura em seus buracos e se esvai junto às críticas que um dia acreditaram capazes de espezinhá-la. Em Que pensam vocês, continuidade da Armadilha, Lamartine perde a memória e, literalmente, enquanto sujeito de conhecimento fica adstrito àquilo que a sua esposa já ex-esposa pode ex-por para ele. Tal poço de fundo sem memória, porém, ressalva coisas e essas são justamente aquelas que dizem respeito tão somente aos Diários do pai. Lamartine torna-se o Diário, corporifica-o, sem conseguir livrar-se do seu conteúdo. Sua vida, contudo, resta. Aos seus filhos passa inventando brinquedos, tais como: uma boneca gigante que seria a esposa Aurora reproduzida, a mãe das crianças, instalada na sala, a espera, com todos, do retorno da mãe verdadeira - que jamais acontece; ou, tal como o jornalzinho do sanatório, o Ataque, no qual Lamartine teria participado: depois inventa outro com os filhos, o Papagaio falador; quando a ex-esposa casa-se com um grande estudioso e conhecedor de provérbios, advém a criação de um jogo, por Lamartine inventado, o provérbio-dominó; sem contar que escreve roteiros para tentar recativar Aurora, em desespero de ser. Seu último brinquedo parece o máximo: jogo eletrostático no qual o jogador não tem controle algum sobre a dança de suas criações papel - que são pedacinhos de dólar ou qualquer outro 
velho papel, colocados dentro de uma tigela de goiaba, cujo solo leva forro de papel fotocopiado e o teto é coberto e bem fechado por papel de acetato: em seu aspecto minúsculo, o sonhador. Em vão, talvez, uma luta desesperada. -Contudo, isso me trouxe aqui, apenas, para apontar, ainda uma vez, as palavras de Benjamin, para quem a brincadeira e assim também a narrativa é sempre um fazer isso e aquilo de novo (Benjamin, 1994, [1928]: 253): habitar uma experiência devastadora, para além de toda segurança ontológica,em cujo hábito o outro que seja em nada é mais duvidoso do que a aparência de ser mesmo, que olhos de vidro ao infinito piscam sem ver. 


\section{Q Bibliografia}

" Azevedo, R. 0 autor desaparecido. Mimeo. (Disponível em: https://www.academia. edu/10996116/O_autor_desaparecido).

" Barcellos, S. da Silva. (2004).Armadilhas para a narrativa: estratégias narrativas em dois romances de Carlos Sussekind. Dissertação de Mestrado, PPGLetras/PUCRJ, Rio de Janeiro.

"Benjamin, W. (2004) "Infância berlinense: 1900 (versão de última mão)" in Imagens de pensamento. Trad. João Barrento, Lisboa: Assírio\&Alvim.

" Campos, R. Salgado. (2008) "Lamartine e seu simulacro brasileiro: Carlos Sussekind e o Diário íntimo". Congresso internacional da ABRALIC. São Paulo: USP.

"Coelho, I. (1989) Diário da loucura: estudo intertextual de Armadilha para Lamartine. Dissertação de mestrado, PPG Literatura/UFSC, Florianópolis.

"Derrida, J. (1991) "Timpanizar - a filosofia" in Margens da filosofia. Trad. Joaquin Costa e António Magalhães. Campinas: Papirus.

"Lasch, M. (2009) "Manicômios, pseudo(auto)biografias e narradores pouco confiáveis: de Machado de Assis a Carlos Sussekind". Estudos de literatura brasileira contemporânea, n. 34. Brasília (julho-dezembro) p. 233-250.

" Lima, L. Costa. (1981) "Réquiem para aquarela do Brasil" in Dispersa demanda (Ensaios sobre literatura e teoria). Rio de Janeiro: Francisco Alves, p. 124-143.

"Miranda, W. de Melo. (1986) "O texto como produção: Bolor e Armadilha para Lamartine". O eixo e a roda, Belo Horizonte, n. 5, p. 176-192.

"Pinto, F. Bortolazzo. (2005) "Autoritarismo e patrulhamento: sobre a recepção de Armadilha para Lamartine, de Carlos Sussekind pela censura e pela crítica literária nos anos 70" in Revista eletrônica de crítica e teoria de literaturas. Porto Alegre, v. 1, n. 1, jul-dez.

" Pinto, F. B. (2004) "Fusão, apagamento, assimetria e representação em Armadilha para Lamartine de Carlos Sussekind e Carlos Sussekind". Revista Letras, Curitiba: UFPR, n. 64, ste/dez, p. 103-123.

"Sousa, L. Neves de. (2007) Os rastros do silêncio: o diálogo entre literatura e loucura em Armadilha para Lamartine, de Carlos \& Carlos Sussekind. Dissertação de Mestrado, PPG Letras/UFMG, Belo Horizonte.

"Sussekind, C. (1991) Armadilha para Lamartine. São Paulo: Brasiliense, 2aㅡ ed.

"Sussekind, C. (1994) Que pensam vocês que ele fez. São Paulo: Cia das Letras.

"Sussekind, C.(2003) Ombros altos. Rio de Janeiro: 7 Letras.

"Sussekind, C. \& Veiga, F. Daudt da. (2001)O autor mente muito. Rio de Janeiro: Dantes. 